\title{
The Construction by Chinese Players of Roads and Housing in Nairobi
}

The transfer of town planning practices between China and Kenya

\section{David Bénazéraf}

Translator. Will Thornely

\section{(2) OpenEdition}

1 Journals

Electronic version

URL: http://journals.openedition.org/chinaperspectives/6392

DOI: 10.4000/chinaperspectives.6392

ISSN: 1996-4617

\section{Publisher}

Centre d'étude français sur la Chine contemporaine

\section{Printed version}

Date of publication: 1 March 2014

Number of pages: $51-59$

ISSN: 2070-3449

\section{Electronic reference}

David Bénazéraf, «The Construction by Chinese Players of Roads and Housing in Nairobi », China Perspectives [Online], 2014/1 | 2014, Online since 01 January 2017, connection on 28 October 2019. URL : http://journals.openedition.org/chinaperspectives/6392 ; DOI : 10.4000/chinaperspectives.6392 


\title{
The Construction by Chinese
}

\section{Players of Roads and Housing}

\section{in Nairobi}

\author{
The transfer of town planning practices between China and Kenya
}

ABSTRACT: As a result of China's increasing presence in Africa, Chinese urban development projects are increasing in number in the continent's cities. In Nairobi, Chinese development aid and state companies are helping to build road infrastructure. Chinese property developers, who are for the most part private, are building and selling housing for the middle classes. Urban projects being carried out by public and private Chinese players are helping the development of the Kenyan capital and the exportation of Chinese urban planning and design practices to Africa. They represent a vector of the power of attraction of China. This article sets out the results of a field study.

KEYWORDS: China-Africa, South-South cooperation, town planning, housing, infrastructure, urban planning and design practices, globalisation, Kenya, Nairobi.

S ince the 2000s, the presence of Chinese players, both public and private, has been growing rapidly over the entire African continent, and in a highly varied range of sectors. Relations between the Chinese state and its African partners have been strengthened with the creation of the Forum on China-Africa Cooperation, (1) and China now occupies a leading position in many African countries. Consolidating its presence there has often been described as a way of safeguarding its supply of raw materials to feed domestic demand. Natural resources have been regarded as playing a structuring role in Chinese-African relations, ${ }^{(2)}$ which helps explain the fundamentally North-South structure of commercial relations between the two continents, with African countries exporting natural or agricultural resources and importing manufactured goods, accordingly limiting the development of local industry and fostering a rentier mentality. (3)

The acceleration in Chinese-African relations has exacerbated the confrontation between donors on a global scale. China is described as an emerging outside player that has come to interfere in relations between old colonised peoples and old colonial empires ${ }^{(4)}$ despite its long-established policy of cooperation on the continent. ${ }^{(5)}$ The "Chinafrica" concept ${ }^{(6)}$ sustains a certain number of myths, for example that of the mass importation of a cheap Chinese workforce. However, China's presence takes on a diverse range of forms that require different combinations of tools and strategies (aid, trade, investment) depending on the specific context of each country. (7) The Chinese are not merely buyers of raw materials; increasingly, they occupy the position of investors. ${ }^{(8)}$ Despite certain constants, their actions vary in the 49 African countries with which China maintains diplomatic relations.
Within the general approach to Chinese-African relations, it is therefore obvious that there should be slight differences in terms of the specific relationships fostered by the Chinese state and the various Chinese players, whether public or private, with the players in African countries. China became the number one bilateral donor to Kenya in 2011, and since 2013 has been the main source of direct foreign investment there. Within the space of a decade, it has become a major player, competing with the country's historical partners and donors. (9) In its role as the economic centre of the region with a generally stable political situation, Kenya is, according to Patrick Mutua Kioko, a secondary headquarters for Chinese economic play-

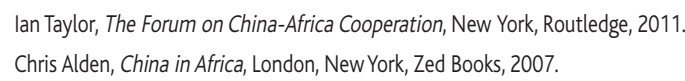

3. Jean-Raphaël Chaponnière and Jean-Jacques Gabas (eds), Le temps de la Chine en Afrique: enjeux et réalités au sud du Sahara (China in Africa: Issues and realities south of the Sahara), Paris, Karthala/Gemdev, 2012.

4. Li Anshan, "Zhongguo dui fei zhengce de tiaoshi yu zhuanbian" (On the adjustment and transformation of China's Africa policy), Xiya feizhou (West Asia and Africa), Vol. 8, pp. 11-20.

5. Jean-Raphaël Chaponnière, "Un demi-siècle de relations Chine-Afrique, Evolution des analyses" (Half a century of Chinese-African relations: Changing analyses), Afrique contemporaine, No. 228, 2008, pp. 35-48.

6. This neologism is a reference to the term "Françafrique," which refers to France's relationship with Africa, and opens the way to a post-colonialist and essentialist reading of relations between China and Africa. It is therefore appropriate to detach oneself from the historical context of colonisation, and to consider "China" not as a monolithic bloc, but as a diverse group of players.

7. Deborah Braütigam, The dragon's gift: The real story of China in Africa, Oxford, New York, Oxford University press, 2009

8. Jean-Bernard Veron, "Éditorial," Afrique contemporaine, No. 228, 2008, pp. 5-9.

9. Emma Mawdsley, "China and Africa: Emerging Challenges to the Geographies of Power," Geography Compass, Vol. 3, No. 1, 2007, p. 421 
ers in East Africa. ${ }^{(10)}$ The two countries maintain relations in a variety of fields, including agriculture, health, tourism, the media, geothermal energy and electricity distribution, road infrastructure, and city services. Compared with 2002, when there were very few Chinese people in Kenya, approximately 10,000 live there now. ${ }^{(11)}$

In Nairobi, various types of Chinese companies and companies of Chinese origin, both public and private, contribute to urban development by constructing buildings (housing and offices), roads, and water conveyance infrastructure, and modernising Jomo Kenyatta International Airport. The aim of this article is to analyse the ways in which Chinese players contribute to urban production in the metropolis of Nairobi. Within the general context of studies on ChinaAfrica relations, it will adopt a micro approach by studying the players that support these relations, based on the results of a field study. Two aspects of urban development have been considered: the creation of major road infrastructure and the building of housing for the solvent middle classes.

As far as urban analysis is concerned, we have attempted, in the tradition of James Ferguson ${ }^{(12)}$ and Jennifer Robinson, (13) to adopt a postcolonial reading that steers clear of the differences between Western cities and Third World cities. Indeed, the urbanisation of Nairobi has been a response to specific dynamics that are neither the result of a teleological process towards a point already reached by and equating to Western modernity, nor conditioned by so-called African archaism. In this article, we will focus on urban planning and design practices or, in other words, on the forms and processes of urban production, and not on the social reception of projects.

Studying Chinese actions also involves an approach detached from the usual categories of analysis that are compartmentalised into development aid, trade, and investments. As identified by Emma Mawdsley, the notion of SouthSouth cooperation or, in other words, cooperation between countries of the South, encompasses many forms of interaction between developing countries: the exchange of resources, skills, technology, knowledge, investment, financial flow, etc. ${ }^{(14)}$ Chinese urban development projects in Nairobi are the fruits of a complex set of interactions involving a range of different players and tools, combining the traditional categories of analysis. Also, it should be clarified at this point that the term "Chinese project" refers in this article to any operation that has been managed by a Chinese company, regardless of whether the contracting authority is Chinese, Kenyan, or Chinese registered in Kenya, and regardless of the origin of the funding (public or private, local or international). A distinction should also be made between China as a state and Chinese players, i.e., a group of companies and individual contractors. This broad meaning leads us to consider companies backed by Chinese capital that are registered in Kenya as Chinese because they are managed by Chinese.

How are urban-development projects implemented by Chinese players in Nairobi? How do Chinese road- and house-building projects fit into the local context? Do they display characteristic features of urban planning and design practices seen in Chinese cities? By focusing on the case of a SouthSouth flow of town planning practices, we have attempted to reconstruct rollouts of Chinese urban development projects outside China's borders by identifying a number of operations and structures that make this transnational phenomenon with local impacts possible.

\section{The need for road infrastructure and housing in Nairobi}

Although only $8 \%$ of Kenyans lived in cities at the time of independence in 1963 , the urban population now represents $24 \%$ of the total, and has shown an increase of $4 \%$ annually since the 1980 s. Nairobi has also experienced strong demographic growth, and the capital had 3.23 million inhabitants in 2010, compared with 400,000 in 1963. Its population is expected to double and cross the six-million threshold by 2025. (15) The city was founded by the British on the high plateaus of East Africa in 1899 as a stopover town on the railway linking the east coast to Uganda. Like many cities on the continent, it has experienced urban development on a scale that is difficult to control.

In terms of urban transport, the explosion in the number of personal vehicles has led to a situation of near-gridlock. The road network inherited from the colonial period is no longer suitable and provides no way of bypassing the city, which means that containers heading from the port in Mombasa to the inland regions of Kenya and adjoining countries still travel through the city centre. Nairobi's municipal road network faces major challenges in terms of redimensioning and organising flows. Chinese development aid and Chinese state companies are currently helping to expand and construct a number of major roads in the city.

As far as new housing is concerned, the national demand was estimated in 2010 at 206,000 new units annually, including 82,000 in urban areas (40\%). Yet actual production fails to exceed 50,000 units annually, representing a shortfall of 156,000 homes each year. (16) We are going to focus specifically on group housing buildings resulting from property development, the only segment of the housing industry, to our knowledge, that currently involves the Chinese. Although growing rapidly, it remains a minority segment for three reasons. First of all, urban housing accounts for only $32 \%$ of Kenya's homes, since the majority of the housing stock is spread over rural areas. Secondly, housing continues to be a largely informal sector in Nairobi, and involves few registration procedures or planning permission applications. ${ }^{(17)}$ Finally, since the state plays virtually no part in the building of new housing, self-building is still the most common way of getting a roof over one's head, and $80 \%$ of inhabitants build their own home. (18) Economic development and the emergence of an urban middle class have facilitated the rapid growth of a property market structured by the presence of local and foreign developers, including a number of Chinese. These meet the demand for group housing in medium-sized buildings, providing a solution midway between makeshift housing (shanty towns) and high-quality detached or luxury housing (town houses or villas with a garden).

10. Patrick Mutua Kioko, "A Study on Chinese Economic Relations with Africa: Case Study, Kenya," Prime Journal of Business Administration and Management, Vol. 2, No. 3, 2012, p. $485 \mathrm{ff}$.

11. Interviews held in Nairobi in November, 2012.

12. James Ferguson, Expectations of Modernity. Myths and Meanings of Urban Life on the Zambian Copperbelt, Berkeley, University of California press, 1999, p. 7.

13. Jennifer Robinson, Ordinary Cities: Between Modernity and Development, London, Routledge, 2006, p. 2.

14. Emma Mawdsley, From Recipients to Donors: Emerging Powers and the Changing Development Landscape, London, New York, Zed Books, 2012, pp. 63-65.

15. United Nations, "World Urbanization Prospects," Department of Economic and Social Affairs, Population Division, 2012, www.un.org/en/development/desa/population/theme/urbanization/ index.shtml (accessed on 5 October 2013). The low level of urbanisation at the time of independence can be explained, in part, by the anti-urban vision of the British civil servants, who did not see the city as a place of economic opportunity: Hélène Charton-Bigot and Deyssi Rodriguez-Torres (ed), Nairobi contemporain: Les paradoxes d'une ville fragmentée (Contemporary Nairobi:The paradoxes of a fragmented city), Paris, Karthala, 2006, p. 18.

16. World Bank, Developing Kenya Mortgage Market, 2011, p. 9.

17. The percentage of inhabitants living in shanty towns in Nairobi varies, depending on the calculation method used, between 32\% (UN-Habitat and Kenya Ministry of Housing) and 70\% (United Nations).

18. Interview in Nairobi with a senior official in the Kenya Ministry of Housing in November 2012. 


\section{Fields of study: Urban roads and group housing}

Several recent Chinese projects have been chosen as fields of study: the Nairobi-Thika Highway motorway that starts in the middle of Nairobi, and three housing complexes. The projects are located within the confines of the Nairobi metropolitan area (the city of Nairobi and neighbouring municipalities), as the urbanised area of the capital extends beyond its administrative boundaries. We carried out the investigation by means of observations and surveys in the field, and through semi-structured interviews with property developers, institutions, and bilateral and multilateral development agencies.

\section{One urban road}

The Nairobi-Thika Highway is the most recent road project to be carried out fully by Chinese contractors. $49 \mathrm{~km}$ in length, this road links the city centre to the northern districts of the capital, continuing as far as the town of Thika. It is the country's first motorway, and along its widest sections it provides four lanes for traffic in each direction. It was opened in November 2012 by Kenya's then President, Mwai Kibaki, after three years of construction works.

\section{Three housing complexes}

We were able to identify around ten public housing complexes built by Chinese developers. Three of these were chosen as case studies. They display features common to all the projects as well as characteristics specific to each property development. The oldest of these projects, which broke ground in May 2010, is the "Great Wall Apartments" complex, ${ }^{(19)}$ located on Beijing road (20) in the town of Mavoko, a municipality adjoining Nairobi in the Machakos district south of the airport. It consists of 528 apartments with a floor area of 70 square meters (three rooms) spread over 11 fivestorey buildings. The complex includes shops and a primary school. The first stone was laid in May 2008 in the presence of the Kenyan Minister of Housing, Soita Shitanda.

The second project, "Sunhills Apartments," is more modest in size, consisting of 168 homes of three, four, or five rooms built on a two-hectare site in the Lavington residential area (Maziwa Ward) west of Nairobi. It was opened in 2011. Finally, the most recent of the three identified projects was still being marketed when we visited, and is located in the north of the city, close to the Nairobi-Thika Highway. The "Jacaranda Gardens" complex is officially comprised of 840 apartments spread over 25 four-storey buildings. (21)

\section{The varied forms of China-Kenyan relations}

\section{Good conditions for a favourable reception}

Faced with the demand resulting from development and urbanisation, the Kenyan authorities are welcoming contributions from foreign countries, and not only members of the OECD development aid committee, with so-called emerging donors forming one alternative. (22) After the 2002 elections, the governing coalition established a political strategy of openness towards Asian countries, which was dubbed the "Look East Policy." (23) This positioning

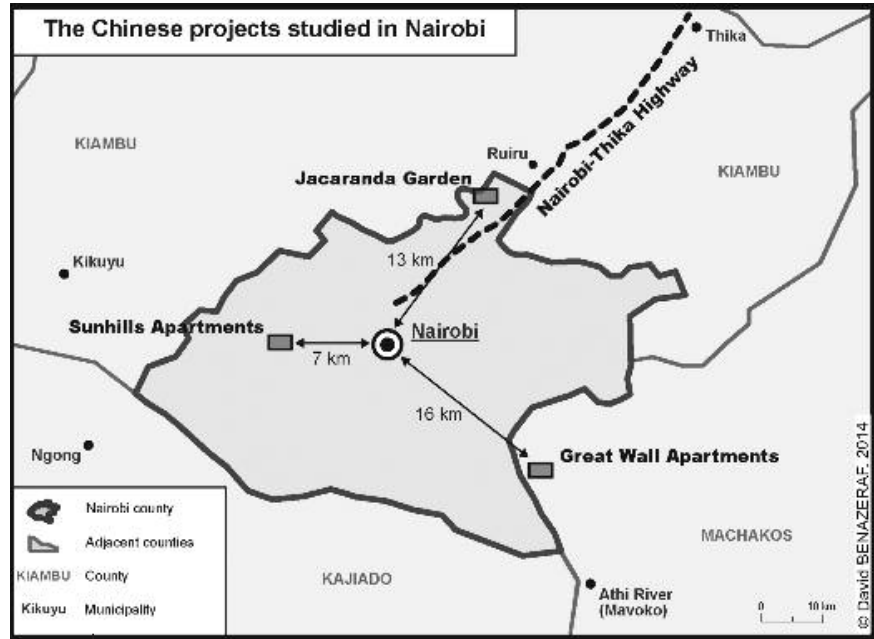

Map 1 - The Chinese projects studied in Nairobi. () David Bénazéraf

is based on the principle according to which Asia, as a result of its recent development, can contribute to Kenya's development at a lower cost than Western countries. Several agreements have been made with China, Japan, and South Korea in the fields of infrastructure, mining prospection, agriculture, retail, etc. The fact that these countries do not impose conditions (24) in terms of policy and reform also has a bearing on why the Kenyan authorities have turned towards them.

At an institutional level, the way foreign funding is received is managed flexibly depending on the partners in question. Direct foreign investment is facilitated by the Investment Promotion Authority, which grants foreign companies licences with no obligation to form a partnership with a local company. In 2012, 67 such Chinese companies were registered in Kenya, (25) including 25 in the public building and works sector, and nine in property. (26) In the case of donors, aid is coordinated on a case-by-case basis by the Department of External Resources of the Ministry of Finance. For example, the European Union draws up a global cooperation programme with the Ministry of Finance at the request of the Kenyan government. Multilateral donors such as the World Bank or the African Development Bank identify the projects on an ad hoc basis, sometimes directly with the ministries in

19. www.erdemann.co.ke/property (accessed on 8 August 2012).

20. The road was given this name as part of the project.

21. This information is taken from the marketing brochure produced by "Jacaranda," an ad hoc subsidiary of the Sietco Group. However, surveys in the field revealed that not all of the advertised buildings have been constructed, and the total number of homes appears to be $25 \%$ less than projected.

22. Emma Mawdsley, From Recipients to Donors, op. cit., p. 2. Emma Mawdsley also suggests the expression "re-emerging donors," a concept more in keeping with reality of the situation.

23. The "Look East Policy": Interviews in Nairobi with the Environmental Management and Planning Department, Kenyatta University, then the think-tank Kenya Institute for Public Policy Research and Analysis (KIPPRA), in November 2012.

24. The conditions imposed in exchange for aid, such as good governance measures or structural adjustments, are viewed by receiving countries as forms of interference.

25. Other sources give a figure of 50 companies (Jean-Raphaël Chaponnière, "La Chine et l'aide à l'Afrique de l'Est" [China and aid to East Africa], in Jean-Raphaël Chaponnière and Jean-Jacques Gabas [eds], Le temps de la Chine en Afrique [China's time in Africa], op. cit, p. 146), or indeed 200 (site of the Chinese Ministry of Foreign Affairs). The number we are using is taken from the list provided by the office of the economic and commercial advisor of the Chinese Embassy in Kenya. However, this list does not take into account small contractors, shopkeepers, restaurant owners, etc. These categories are not taken into account in the statistics.

26. It should be noted that some companies belonging to the property category carry out both development and construction operations. 


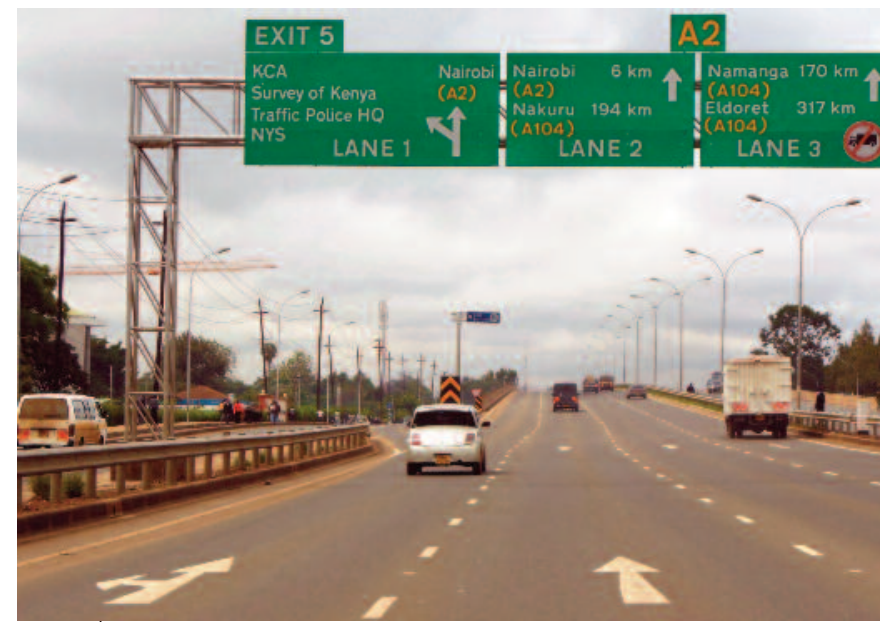

Photo 1 -The Nairobi-Thika Highway, built by three Chinese companies. ๑ David Bénazéraf

question. As far as bilateral Chinese aid is concerned, it is difficult to identify, with certainty, the level at which projects are negotiated, owing to a lack of transparency on both the Chinese and Kenyan sides. However, it seems that such talks take place at a high level when Chinese loans are at stake. Emma Mawdsley explains that relations conducted at the elite level make it possible to bypass the usual institutional procedures. ${ }^{(27)}$ Local authorities also foster relations with private Chinese investors. For example, in the case of the Great Wall Apartments property project, the mayor of Mavoko helped identify a suitable site. ${ }^{(28)}$

\section{Modes and vectors of transmission at several levels}

China-Kenya relations are maintained at a number of levels, through bilateral or multilateral cooperation and through a growing number of private investments, and it is not always clear at what point one merges with the other on a scale ranging from official development aid as defined by the OECD through to purely commercial contracts. ${ }^{(29)}$ Indeed, China should not be seen as a monolithic object, given the diversity of its players and of the contexts in which it takes action. It is also helpful to distinguish between official state-state cooperation, the support given by the Chinese state to Chinese companies, and the commercial activities of independent companies. The full range of tools, as well as the intricate interactions between them, can be seen in the field of urban development. Four forms can be identified within the two broad categories of development aid and the business sector. Whereas road-building falls largely into the first category, new housing projects are mostly the concern of the commercial sector.

In the case of roads, bilateral aid is provided by China for Kenya in the form of concessional loans, the conditions of which are not made public. However, what is known is that Chinese loans generally have the advantage of longer grace periods ${ }^{(30)}$ and longer repayment schedules than Western loans. ${ }^{\left({ }^{31}\right)}$ In the city of Nairobi alone, at least four loans have been granted since 2008 for the north and south bypasses, Ngong Road, and for one of the three sections of the Nairobi-Thika Highway. This is categorised as aid because the contracts are systematically granted to Chinese state companies (even though their ad hoc subsidiaries are registered locally as private companies, the capital is still of Chinese origin). (32) Moreover, Chinese companies also take action through funding provided by bilateral or multilateral donors after winning international calls for tenders. This applies, for example, to the two other sections of the Nairobi-Thika Highway, which were funded respectively by the African Development Bank and the World Bank. ${ }^{\left({ }^{33}\right)} \mathrm{An}-$ other example is that of the Chinese company responsible for repairing the runway of Nairobi International Airport, which won a call for tenders issued by the French Development Agency (AFD). (34) For projects of this kind, the players are always state companies encouraged by the Chinese government to operate outside China as part of the policy referred to as "going out." (35) Unlike many local companies, most are classed in Kenya's "A" category, which means they are capable of honouring contracts of more than five billion Kenyan shillings (the equivalent of US\$57 million). The Nairobi-Thika Highway was thus funded in three sections (bilateral Chinese aid, the World Bank, and the African Development Bank), but was built completely by Chinese companies (Sinohydro, China Wuyi, and China Shangly). ${ }^{(36)}$

Although residential construction is carried out by private contractors, such operations are able to raise a form of Chinese state aid or Chinese capital. Most of the Chinese players in this sector are small and medium enterprises that have expanded their operations following success in China or after having set up locally in Kenya. For example, the owner of the Chengdu Guanglin Company, which built the Sunhills Apartments residence, is based in China. He invested alone in order to build his project, and is represented in Nairobi by a young Chinese graduate in English from Sichuan University in Chengdu. ${ }^{\left({ }^{77}\right)}$ The Jacaranda operation was conducted by a provincial-level Chinese state company, Sichuan International Cooperation Corporation (SIETCO), but it operates in Nairobi as a private company, even though it raises Chinese public capital. (38)

Finally, the Great Wall project was carried out by the Erdemann Company, whose owner, Yang Zeyun, has lived in Nairobi since 1993 and entered property development in 2002 after establishing a successful import-export business. He also has other interests in tourism and the production of alcohol for export to the Democratic Republic of Congo. His wife manages the accounts department and shares her office with three Kenyan employees. The Great Wall project is the result of a more complex set-up combining Chinese state funding (the Chinese Development Bank) with local funding. The building work was carried out by the China Wuyi company, which also has a presence in the road market. The Erdemann Company borrowed 500 million Kenyan shillings (approximately US\$5.8 million) from a local bank, Housing Finance, ${ }^{(39)}$ to carry out the building work. At the same time, the Kenya Development Bank granted mortgage loans to individuals in order to enable them to buy the apartments; this was made possible by a line of

27. Emma Mawdsley, From Recipients to Donors, op. cit., p. 106.

28. Interview in Mavoko with Stanley Shibayilu, vice-mayor of Mavoko, in November 2012.

29. Deborah Braütigam, The dragon's gift, op. cit., p. 74 ff.

30. The period between the payment of the loan by the lender and the actual start of repayments by the borrower.

31. Deborah Braütigam, The dragon's gift, p. 275.

32. Interview in Nairobi with the European Delegation, then with the office of the economic and commercial advisor of the Chinese Embassy in November 2012.

33. China has been a member of the World Bank since 1980 and the African Development Bank since 1985. Chinese companies are eligible for the projects of these two donors.

34. Interview in Nairobi with a Western public works company in November 2012.

35. For more information on the "going out" policy, see "The risks of a 'going out' strategy?", China Analysis, No. 36, February 2012.

36. Chinese Ministry of Commerce (MOFCOM), http://french.mofcom.gov.cn/article/zt_fslcsa/lanmufc/201207/20120708242192.shtml (accessed on 17 May 2013).

37. Interview in Nairobi with a representative of the Chengdu Guanglin company in November 2012.

38. It is actually a subsidiary. Chinese State companies can set up private subsidiaries abroad.

39. Interview in Nairobi with a manager at Housing Finance in November 2012. 
credit provided by the China Development Bank, a Chinese state bank. For this reason, this property operation was presented as a Chinese-Kenyan cooperation project. ${ }^{(40)}$ However, insofar as the China Development Bank issued non-concessional loans, this project cannot be considered genuine development aid. ${ }^{(41)}$ It is more comparable to a form of indirect support for a commercial project benefitting two Chinese companies: a property development SME, Erdemann, and a construction company, Wuyi. Having said that, this line of credit still helps support the mortgage loan market, and contributes to positive relations between China and Kenya.

The different forms of Chinese intervention provide evidence of the diversity of players and their ability to integrate themselves into the local economy and, where necessary, to raise funding.

\section{A donor that is not a member of the Development Assistance Committee}

China occupies an unusual position as a donor. In Nairobi, it does not participate in coordination meetings with other donors, which adds to the lack of transparency. Nor is it a member of the working group on urban development run by the office of the World Bank in Kenya. ${ }^{(42)}$ Unlike other donors becoming involved in urban development, Chinese involvement in projects is concentrated in the operational dimension of urbanisation; the Chinese contribute neither to strategic planning aspects, as do the Japanese and the French, for example, nor to strengthening the capacities of local institutions, an area in which the World Bank is active. For example, in 2006, the Japan International Cooperation Agency (JICA) defined the priorities for Nairobi's roads. According to Joseph Onjala, the Chinese simply intervened for the purpose of an operational feasibility study following the visit of President $\mathrm{Hu}$ Jintao in 2006. ${ }^{(43)}$ Moreover, urban development does not appear to be included in the short training programmes offered by China to more than 300 Kenyan officials and technicians each year; in contrast, Japan funds long-term scholarships for Masters programmes in town planning. ${ }^{(44)}$

The Chinese position, on the other hand, is concentrated in sectors in which other donors are not present. An exception to this tendency is the contribution it makes to building mid-range group housing, even though this is not genuine development aid; donors who are members of the DAC focus more on programmes to improve housing in the shanty towns. As underlined by the ex-President of Senegal, Abdoulaye Wade, China's positioning also meets concrete needs: "China's approach to our needs is simply better adapted than the slow and sometimes paternalistic approach of Europe." (45)

\section{Chinese development aid for Nairobi's road infrastructure}

\section{An alternative to the donors of the DAC}

Despite the lack of official figures, the total sum of China's investments in the road infrastructure sector in Nairobi can be valued at around US\$500 million. ${ }^{\left({ }^{46)}\right.}$ China occupies the third position in this field, after the World Bank and the African Development Bank, and ahead of the European Union. Chinese companies are responsible for the construction of a number of roads that are being built in Nairobi or have already been completed.

When examined alongside the methods adopted by other bilateral donors in such projects, such as the European Union or Japan, the Chinese approach displays several differences. The speed of completion of projects and the lower costs consistently stand out, and can be explained primarily by the fact that the project cycles are shorter. Whereas the European Union will take around ten years to complete a road-building project, from identifying the project to operational delivery, the Chinese never exceed four years. The preparatory phases are carried out much faster. In European-run projects, it can take approximately six years to identify, draw up, approve, and then sign a contract, but the Chinese need no more than six months to complete the same process. This difference can be explained in part by the briefer nature of studies carried out by Chinese companies, while in all European projects, environmental impact studies and detailed plans are produced by independent consulting companies before a building contract is even signed. In Chinese projects, the exact opposite takes place: studies are often carried out internally by the company that holds the contract, after it has been awarded.

The Chinese practice of tied aid, characterised by the absence of international calls for tenders, also makes it possible to avoid long procedures and to get projects off the ground quickly. ${ }^{(47)}$ Turnaround times are also shortened by the fact that there is no social approach to projects. For example, while the Europeans and Japanese provide compensation packages for inhabitants who are forced to move out of an area to make way for projects, the Chinese attract criticism for evicting people. When houses were destroyed during the construction of the Nairobi-Thika Highway, the Kenyan government apparently did not intervene, and even implemented security measures for the Chinese companies on occasion. ${ }^{(48)}$ This understanding allows the authorities to hold the Chinese responsible while also avoiding the cost of re-housing inhabitants. Finally, the proportion of management tasks held by Chinese managers compared to local employees is higher than in projects run by Western companies. Indeed, an additional hierarchical level is occupied by expatriate managers in Chinese companies, down to the works foreman level. (49) This increased local presence helps better manage schedules.

\section{Short-term results}

Although Chinese practices guarantee swift, concrete results, questions remain regarding the quality of the delivered projects. The perception of local public opinion appears to be positive on the whole. The population has the impression that progress is being made when it sees projects taking

40. "Chinese bank-financed housing project kicked off in Kenya," Xinhua, 31 May 2008, http://news.xinhuanet.com/english/2008-05/31/content_8287705.htm (accessed on 8 August 2012); interview in Nairobi with Stanley Shibayilu, vice-mayor of Mavoko, then in Nairobi with Yang Zeyun, a property developer, and manager of Erdemann Property Limited, in November 2012.

41. A concessional loan is granted with improved conditions relative to the market conditions: Olivier Charnoz and Jean-Michel Severino, L'aide publique au développement (Public development aid), Paris, La Découverte, 2007, p. 11 ff; Deborah Braütigam, The dragon's gift, op. cit., p. $115 \mathrm{ff}$.

42. Members: Swedish Embassy, French Development Agency, Italian cooperation, Japan International Cooperation Agency (JICA); Interview with the Kenyan office of the World Bank, November 2012.

43. Joseph Onjala, "A Scoping Study on China-Africa Economic Relations:The Case of Kenya," University of Nairobi, Institute for Development Studies, 2008, p. 46.

44. Speech by the economic and commercial advisor of the Chinese Embassy in Kenya, March 2012; Interview with the Japan International Cooperation Agency, November 2012.

45. Quoted in Deborah Braütigam, The dragon's gift, op. cit., p. $135 \mathrm{ff}$.

46. Interview in Nairobi with the European representation in November 2012.

47. Chinese companies are, however, brought into competition with other Chinese companies.

48. Interviews in Nairobi with the French Development Agency, Japan International Cooperation Agency, then with the European Representation in Nairobi in October and November, 2012.

49. Interview in Nairobi with a Western construction company in November 2012. 
shape and traffic moving more smoothly, ${ }^{(50)}$ and leaders are sensitive to such sentiments. Nevertheless, discontent is expressed against Chinese cooperation in the infrastructure sector. A number of aspects of this involvement attract criticism: machines do not remain on site once the works are complete; the Chinese do not use locally qualified labour; the salaries paid to the local workforce are considered too low; and certain laws are not observed. ${ }^{(51)}$ Other criticisms also refer to uncertainty regarding the quality and life-span of the end products. These considerations were emphasised in all the interviews carried out in Nairobi.

The Nairobi-Thika Highway was analysed at the time of its opening in November 2012, and despite a generally positive reception owing to the scale and dimensioning of the infrastructure, observations made on the site reveal defects: there are cracks in the concrete in elevated parts of the road, pieces of iron protrude from the reinforced concrete, and the paving stones display differential settlement ${ }^{(52)}$ of the pavements at junctions. One may question the quality of the engineering and to what extent it complies with local standards. For example, the height of the edges of the pavement presents a risk that car tyres may burst in the event of impact. This fails to comply with Kenyan standards, which were inherited from the British Empire. Finally, little real consideration appears to have been given as to how the project will fit in with its surroundings as a whole. For example, there are no kerb cuts ${ }^{(53)}$ where the road meets certain secondary roads or private entrances, giving the impression of an object disconnected from its surroundings, like a line linking several locations without considering other points of access or the secondary road network. This phenomenon is often seen in China, where the speed at which projects are carried out limits attention to detail and the quality of the finished product.

It appears that even the local context has not been taken into account: when the project was delivered, not a single safe pedestrian crossing had been put in place, despite the high number of pedestrians. They were therefore forced to cross what had once been an old road but was now a motorway, on foot. After several fatal accidents, work was underway on pedestrian walkways in November 2012, resulting in additional costs. ${ }^{(54)}$ Reflecting the speed of urban development seen in Chinese cities, the rapid completion of Chinese projects has the advantage of meeting demand quickly and at a lower cost. However, it is too early to measure how well they stand the test of time, and the moderate initial costs could turn out to be higher over the long term.

\section{Does housing built on a commercial basis fit into the local context?}

\section{A profitable segment of the housing market...}

Armed with China's experience of swift and large-scale construction of urban housing buildings, ${ }^{(55)}$ Chinese contractors have been building housing complexes of between 100 and 600 apartments in Nairobi. All the projects we looked at involved high-density housing intended for the solvent middle classes, i.e., those working in the formal employment sector whose jobs enabled them to take out a loan. This applies to approximately $11 \%$ of the urban population (2.4\% of the national population). ${ }^{(56)}$ In Nairobi, access to home ownership is largely funded by mortgage loans that command especially high interest rates, averaging around $14 \%-16 \%$ but rising to as much as $24 \%$. These high rates are explained by the elevated risks resulting from the complexity of the legal framework and the difficulty of ensuring repayment due to uncertainty in the job market. Most of the apartments are sold off-plan, or even over the Internet, before work starts. They are intended to be the main home of the buyer or are purchased as an investment to be rented out. ${ }^{(57)}$ The developers are granted a portion of the liquid assets before work begins on the site. Therefore, this segment of the market is aimed at high and middle incomes from the formal employment sector.

Chinese projects are spread all over Nairobi and its environs, in areas that currently have a low population density. The Great Wall and Jacaranda residences are located in two of Nairobi's urban expansion areas, respectively in the town of Mavoko, an essentially industrial municipality whose residential districts are growing rapidly owing to rising property prices in the districts close to the centre and the airport, and in the northern districts. Both areas are considered to have a low agricultural potential. The Sunhills project is located in a residential district where housing complexes are being built in a context of urban renewal, on plots of land previously occupied by villas with gardens. The developers involved in the projects in question are therefore implementing their projects either in the existing urban fabric or on the fringes where urbanisation is underway.

There is no typical operational and financial set-up. As already indicated, the implementation of the Great Wall project involved a developer established in Nairobi, a Chinese state construction company, and funding from local, private, and Chinese state sources. The last apartments that were still unsold before the opening were marketed by a local estate agent, Seb Estates, which is also in charge of property management. ${ }^{(58)}$ The Sunhills project is based on a far more straightforward model that is actually completely integrated in terms of design, management, construction, and sale. It was carried out using shareholders' equity with capital raised from private Chinese sources. Management of the property was expected to be ceded back to a local company once all of the apartments were sold. ${ }^{(59)}$ The profits generated by this project are as high as $100 \%$. The main similarity between the projects lies in the search for maximum profitability, sometimes to the detriment of local regulations.

\section{... taking advantage of the inadequacies of local governance}

Urbanisation in Nairobi is characterised by a lack of urban planning, a high level of land tenure insecurity and a limited observance of existing rules and practices. The last master plan in force in Nairobi was drawn up in 1972 and

50. Daily Nation, 8 April 2013, www.nation.co.ke/News/Thika-superhighway-becomes-model-roadin-rainy-season/-/1056/1742508/-/l3e2hxz/-/index.html (accessed on 21 May 2013).

51. Interview in Nairobi with the Kenya Institute for Public Policy Research and Analysis (KIPPRA) think-tank in November 2012

52. Different levels due to the instability of the substrate.

53. A lowering of the edge of the pavement in order to allow cars to cross, for example at a carriage entrance.

54. Interview in Nairobi with the JICA in November 2012

55. For more information on the property sector in China, see Victor Sit (ed), Chinese City and Urbanism, Evolution and Development, Hackensack, NJ, World Scientific, 2010.

56. Daily Nation, 23 May 2013, www.nation.co.ke/Features/DN2/What-is-financing-Kenyas-construction-boom/-/957860/1661210/-/1v23rx/-/index.html (accessed on 23 May 2013); World Bank, Developing Kenya Mortgage Market, 2011, p. 18.

57. The distribution of owner-occupiers and tenants is governed by private arrangement. In order to make an accurate calculation, it would be necessary to conduct quantitative surveys of the inhabitants, which is beyond the remit of this research.

58. Interview in Mavoko with a Seb Management agent in the "Great Wall" complex, then in Nairobi with Yang Zeyun in November 2012.

59. Interview in Nairobi with a representative of the Chengdu Guanglin company in November 2012. 
expired in 2000, and the drawing up of new real estate laws is taking place slowly. The multiplicity of planning bodies (Nairobi City County, Ministry of Lands, Ministry of Nairobi Metropolitan Development) does not make it any easier for public authorities to act. As far as town planning procedures are concerned, the municipality of Nairobi examines only 250 planning permission applications per month, despite the implementation of an online system for submitting such applications in 2012. ${ }^{(60)}$ With the exception of major developers and people able to obtain a mortgage loan, most building work is carried out without permission, outside the control of the municipality. (61) Urban development is essentially based on private initiative. Since most of the land in Nairobi is privately owned, developers canvass landowners directly depending on the real estate opportunities, and then check the title deeds with the Ministry of Lands. ${ }^{(62)}$ The setting up of projects is tailored more to economic criteria than to a planned development strategy.

Chinese developers seem to be taking advantage of the inadequacies of local governance in order to increase the profitability of their projects. Whereas the average density of housing in Nairobi is only 40 units per hectare, the Chinese projects we studied all exceed this threshold, with 60 or even 80 apartments per hectare. The height limits in force are also sometimes exceeded. For example, in the Jacaranda Gardens complex, up to three additional floors have been built on certain buildings compared to the specifications submitted in the planning permission application. Some project applications submitted by Chinese developers are refused planning permission because of the excessive density of housing units. However, when faced with developers who submit an acceptable application only to subsequently modify the plans, the body that supervises building sites for the town planning department of Nairobi City County can merely record the irregularities, because it lacks adequate coercive means. By exceeding density and height regulations, developers are able to pay less development tax, since this is calculated based on the projects actually submitted, and to sell at competitive prices. ${ }^{(63)}$ The authorities are stuck between the major need for housing and the hostility of the population to an excessive density of housing units.

\section{A response suited to the demands of the market?}

Chinese-built housing complexes offer a certain number of advantages. They meet the same needs as those imposed by urban development in China in terms of the speed, density, and large scale of the projects. ${ }^{(64)}$ Buildings are completed more quickly than those constructed by local companies. Projects are carried through to completion within the stated turnaround times. The quality of the buildings appears to be appreciated by the inhabitants, and is considered to be better. ${ }^{(65)}$ The apartments are designed to meet the demands of the middle classes insofar as the facilities provide for a standard level of comfort (fitted kitchen, bathroom, running water, Internet connection, electricity). Jacaranda and Sunhills each have a swimming pool, although neither was operating when we visited. The Great Wall complex has several shops and a primary school. The gated design of the complexes provides a feeling of security.

However, as in the case of road infrastructure, questions can be raised concerning the sustainability and quality of the projects. The scale of the most recent project, Jacaranda Gardens, with its planned 840 apartments, is perhaps overambitious in its scope, and six of the 25 buildings in the original plans have not been built. The complex was also supposed to include a small shopping centre and restaurants, according to the brochure and the model of the site, but these had not been built when we visited. The failure

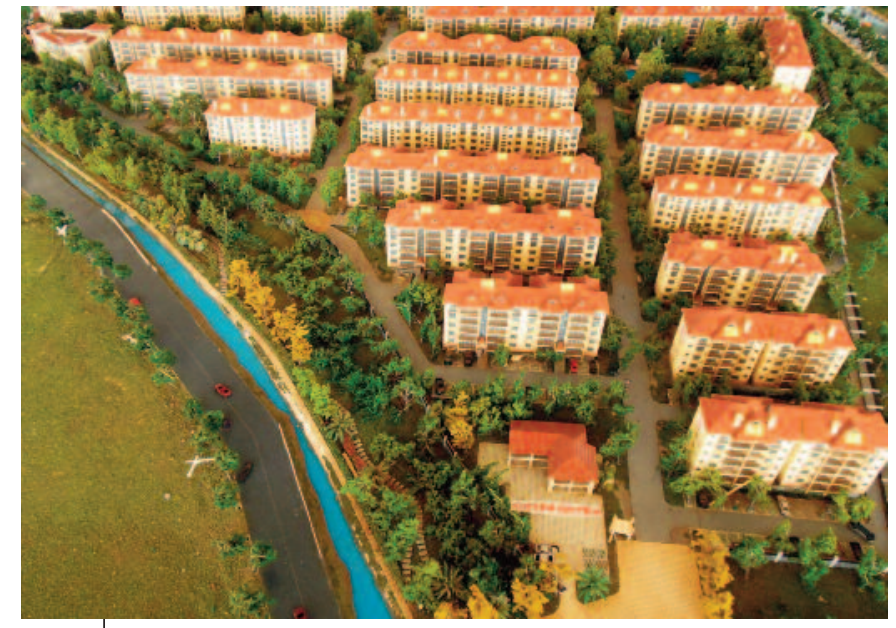

Photo 2 - Model of Jacaranda Gardens, showcased in the sales office of the residence. $\odot$ David Bénazéraf

to honour announcements and promises is a common practice of property developers in Chinese cities. ${ }^{(66)}$ Moreover, the buildings are already showing signs of ageing, with cracks, flaking paintwork, traces of damp, and small piles of rubble. After rain at Sunhills, puddles of water form in stairwells in the communal indoor areas. Some of the window openings are too low to the ground, raising security issues. In Jacaranda, the internal finish to the apartments was in a poor condition even before they were sold. For example, the floorboards feel slightly loose underfoot.

\section{A housing style resulting from a mixture of models}

\section{Local influence}

Although there are a few Kenyan references, our analysis picked up several markers of features imported from China in terms of both the facilities and the design. The field data was analysed, compared from an architectural point of view to Chinese housing, such as in the residential districts in the north of Beijing, and translated into research conclusions.

The external architecture of the three complexes we studied is Kenyan in appearance. They feature slanting tiled roofs with dormer attic windows, similar in appearance to those of villas. At Great Wall and Jacaranda, there are also windows with small panes, which are typical of the colonial villas left by the British Empire. The exterior of the buildings was designed by local architects in the case of all the projects, because only architects registered

60. In comparison, a city such as Paris, which possesses barely any urbanisable land and whose intramural growth is almost zero, receives approximately 125 applications per month.

61. This applies to some Chinese projects; interview with the head of town planning of Nairobi City Council in November 2012 (Nairobi City Council became Nairobi City County in March 2013 after the reform of local authorities came into force).

62. For more information on the land system, see articles by Claire Médard, "Nairobi: acteurs et enjeux d'une planification détournée" (Nairobi: Players and stakes of a back-door planning system) and Winnie Mitullah, "Local Political System of Nairobi," in Hélène Charton-Bigot and Deyssi Rodriguez-Torres (eds), Nairobi contemporain (Contemporary Nairobi), op. cit.

63. www.nairobicity.go.ke (accessed on 1 August 2012).

64. Su Yansheng and Ren Chenchen, "Zhongguo chengshi guihuasheji de haiwai fazhan" (Development of design-in-china urban planning projects abroad), Beijing, Time+Architecture, January 2010.

65. Interview in Mavoko with a resident of the "Great Wall apartments" in November 2012.

66. Luigi Tomba, "Residential Space and Collective Interest Formation in Beijing Disputes," The China Quarterly, No. 184, 2005, p. 934 ff. 


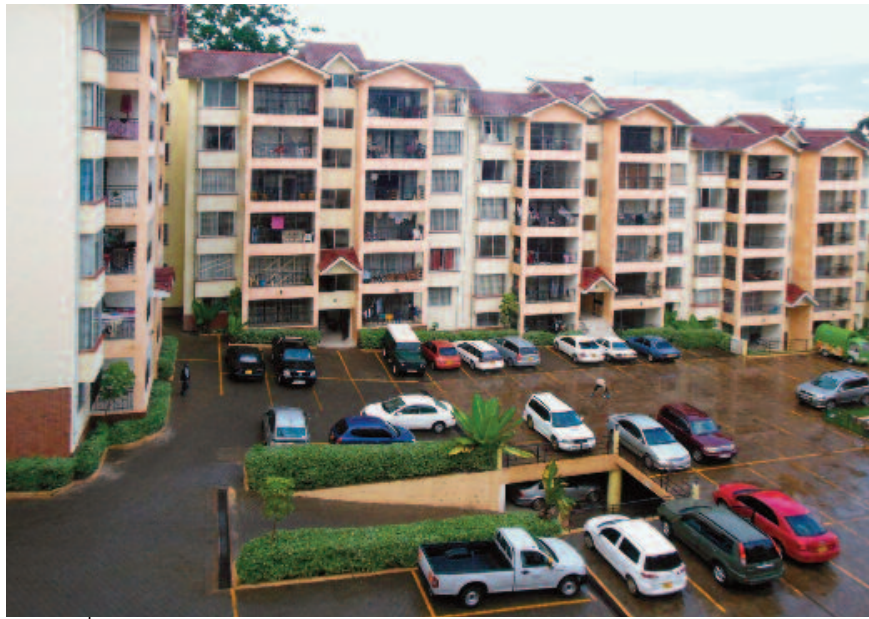

Photo 3 - View of the Sunhills residence apartments. ๑) David Bénazéraf

in Kenya are authorised to certify architectural designs in the country. However, in reality the projects are the result of work carried out jointly with Chinese designers. The separation between the design of an outer shell and the internal composition of the building is a common practice in Chinese architecture and town planning agencies such as the Beijing Tsinghua Urban Planning \& Design Institute and the Shanghai Tongji Urban Planning \& Design Institute: ${ }^{(67)}$ an architect designs an overall plan including the broad brushstrokes of the external design, and the detailed plans are then drawn up by separate engineering and design departments. ${ }^{(68)}$ Moreover, it appears to be difficult for Kenyan architects to work with their Chinese counterparts, because the latter show little consideration for the local context. ${ }^{(69)}$

\section{Traces of imported Chinese practices}

The structure of the buildings and the indoor arrangements were designed either in China, as in the case of Great Wall and Jacaranda, or in Kenya by Chinese engineers working in Chinese companies, as in the case of Sunhills. The scale of the buildings and the way in which the apartments are organised bring to mind the units produced in Chinese housing complexes. The composition of the high-rise buildings typical of Chinese residential districts can be seen in the projects we studied. The thin design of the structures means daylight enters every apartment from both sides of the building. A single stairwell provides access to two homes on each floor rather than each building having a single stairwell providing access to all the apartments via a shared central corridor. Even the format of the stairs is designed to Chinese standards, with the same number of steps per half-landing and the same style of metal guardrails. Most of the homes are designed for a small family, having only two bedrooms. While such a format might be suitable for Chinese families, it is not necessarily ideal for Kenyan families. The entrance door opens directly into the living room, as there is no entrance hall between the outside and inside. The fitted kitchen is not provided with a space for the fridge, which is usually to be found in the living room. This is a characteristic feature of many Chinese apartments designed for middle class residents. ${ }^{(70)}$ The kitchen also has a small internal balcony with washing machine connections.

The decoration and furnishing of the model apartments in Jacaranda Gardens are characterised by their Western inspiration, with imposing chandeliers in the ceiling, still life paintings on the walls, lace curtains and cushions with pompoms, heavy furniture made from varnished wood, etc. This style is similar to that seen in luxury apartments sold on the Chinese market. Jacaranda Gardens also has a brochure of furniture lines on its website, which is translated into English but still features a few words in Chinese. ${ }^{(71)}$ This suggests that the products are most probably also available on the Chinese market. The style is characterised by its supposed luxury, and conveys an image of upward social mobility. Therefore, Chinese developers are designing apartments that symbolise social success, just as they are used to doing in China. Furthermore, the outdoor spaces of Jacaranda Gardens display two other Chinese features: a small pavilion in the style seen in Chinese gardens, with stools made from solid pieces of stone imported from China, and a landscaped composition made from stone. Although the materials of the main structure of the buildings are purchased in Kenya, all the lighter equipment, such as doors, locks, switches, bathroom fittings, electricity meters, etc., are imported from China. They all display the logo of a Chinese brand in Chinese characters or Pinyin. Even the controls on boilers, entry phones, and extractor hoods are in Chinese, with no translation provided.

The computer-generated images included in the Jacaranda sales brochure deserve attention. On the television, it can be seen that the presenter or singer has an Asian profile. It could be assumed that these visuals have come from a Chinese image bank. For example, there are no Kenyan families or executive officers next to the swimming pool; instead the people have a western or Asian appearance, including one couple holding a single child by the hand. These computer-generated images are highly evocative of those used in China. The models of coloured bushes also resemble, in all aspects, the images used in the property brochures of Chinese architecture agencies.

Although the Chinese Embassy in Nairobi states that China is not seeking to export its model but to "share its experience" with Kenya, ${ }^{(72)}$ the housing built by Chinese developers nevertheless reflects an asymmetrical relationship. The construction of this housing is influenced by the methods of practitioners who have gained experience in China and bring with them their own customs, and by the use of imported equipment. Although the purpose of this article is not to investigate the possible existence of a political project in the exercise of soft power by China, ${ }^{(73)}$ the projects we studied provide something of a model example. As observed by Deborah Braütigam, the success of Chinese development is seen as a source of attraction for developing countries:

A programme that combines government subsidies with the transfer of a highly successful aspect of China's own development model could be intended primarily as a tool of soft power. ${ }^{(74)}$

The actual projects and their designers convey an image of success and contribute to globalisation and to the progress of cultural reference systems:

67. Although they are based in universities, these institutes are actually operational agencies that design projects all over China.

68. The author's personal and professional experience in China.

69. Interview with the head of town planning of Nairobi City Council in November 2012

70. The author's personal and professional experience in China.

71. www.jacarandagardens.co.ke/series-navigation.html (accessed on 5 November 2012).

72. Speech by the economic and commercial advisor of the Chinese Embassy in Kenya, 2012.

73. Joseph Nye, Soft power: The means to success in world politics, New York, Public Affairs, 2004.

74. Deborah Braütigam and Tang Xiaoyang, "Economic Statecraft in China's New Overseas Special Economic Zones: Soft Power, Business or Resource Security?", International Affairs, Vol. 4, No. 88, 2012, p. 802 
The increased flow of experts and expertise and the diversification of their places of origin cannot be dissociated from a recomposition of structures of economic and political domination. Nomadic expertise is therefore nothing more than the privileged expression of these power struggles. ${ }^{(75)}$

Identifying sources and markers of identity is a complex process, because they are the result of complex interactions in time and space. It would be hasty to conclude that the housing built by Chinese developers in Nairobi constitutes a simple and literal transposition of a so-called Chinese model. Indeed, Chinese housing complexes are themselves the result of a mixture of models imported from abroad.

The Chinese model of urban group housing in a complex (shequ 社区) is itself the result of a blend of influences, including the Chinese Communist system of population control, inherited from the work units (gongzuo danwei 工作单位), an ancient urban legacy, and the introduction of liberal property reforms by international institutions such as the World Bank. ${ }^{(76)}$ The Chinese housing market has also been directly influenced by major property groups in Singapore who have been encouraged by their government to conquer Asian markets. ${ }^{(77)}$ The appearance of grouped residential districts, which are densely packed and gated, meets the needs brought about by the emergence of a solvent middle class that is able to attain a better standard of living.

\section{Conclusion}

China is unquestionably participating in the urban development movement in Nairobi and its surrounding area. Although the city's urban infrastructure is still reliant on resources from the colonial period or the early years following Independence, the highly operational dimension and speed of completion of large-scale Chinese road and housing projects are helping the current drive to make up for lost time. Chinese development aid and private Chinese investors differ from other foreign players in that they offer more immediate answers to the needs of the population. These projects are not preceded by long preliminary studies and coordination meetings, or subject to environmental and social conditions or good governance. The way in which the urgency and scale of needs are met demonstrates a pragmatic approach. As emphasised by one analyst from the Kenyan government think-tank: "The flow of concepts from the North may not really address our priorities." (78)

Beyond the actual material contribution, public and private Chinese players are helping strengthen the power of attraction of China, even if the exportation of town planning practices is the result of a wider transnational process of circulation of urban models, and is dependent on them fitting in at a local level. Without claiming to impose any model whatsoever, these players are nevertheless bringing their own practices and know-how onto the African continent. The Chinese urbanisation experience cannot be transposed to the Kenyan context, but nevertheless appears to be a success there. By playing an increasing role, Chinese players are supporting the rise of a middle class, and it will be worth studying the local reception of Chinese projects a few years down the line.

\section{Translated by Will Thornely.}

I David Bénazéraf is a PhD student in urban geography at the Sorbonne University in Paris, Laboratoire Prodig CNRS-IRD, a contributor to the Asia Centre, and an affiliate researcher at the Centre for Chinese Studies at Stellenbosch University, South Africa (david.benazeraf@gmail.com).

75. Éric Verdeil, "Expertise nomades au Sud, éclairages sur la circulation des modèles urbains" (Nomadic expertise in the South, perspectives on the circulation of urban models), art. cit., p. 168, http://geocarrefour.revues.org/1145 (accessed on 15 November 2011).

76. David Bénazéraf, De l'unité de travail à la communauté résidentielle : les impacts de la réforme du logement en Chine : le cas du quartier Fangzhuang à Pékin (From the work unit to the residential community: The impact of housing reform in China:The case of the Fangzhuang district of Beijing), under the direction of Thierry Sanjuan, Masters dissertation, 2007, p. $16 \mathrm{ff}$.

77. Xavier Guillot, "Flux économiques, transferts d'expertises et production immobilière haut de gamme en Asie orientale" (Economic flows, transfers of expertise, and luxury property production in East Asia), Géocarrefour, Vol. 80, No. 3, 2005, p. 175 ff., http://geocarrefour.revues.org/1145 (accessed on 15 November 2011).

78. Interview in Nairobi with the Kenya Institute for Public Policy Research and Analysis (KIPPRA) think-tank in November 2012. 